\title{
Influence of Echinococcus multilocularis infection on immune response of mice and their offspring
}

\author{
K. REITEROVÁ*, D. ANTOLOVÁ
}

\author{
Institute of Parasitology of the Slovak Academy of Sciences, Hlinkova 3, 04001 Košice, Slovak Republic, \\ E-mail: reiter@saske.sk
}

\begin{abstract}
Summary
Parasitic infection during pregnancy represents a serious stress factor and affects the course of pregnancy and the foeto-maternal relationship. The infection may not clinically manifest itself, however it can modulate the immune response of the offspring for a long-time. The influence of secondary Echinococcus multilocularis infection on the proportion of CD4+ and CD8 $+\mathrm{T}$ cells and the level of anti-Echinococcus antibodies were studied in Balb/c mice. The female mice were infected with homogenised metacestode material containing 2000 E. multilocularis protoscoleces (Group 1, 2). Group 1 was fertilised on day 60 post infection, while Group 2 remained unfertilised. Group 3 was uninfected and fertilised on the same day as Group 1. The numbers of both $\mathrm{T}$ cell subpopulations were higher in non-pregnant than in pregnant mice. In late pregnancy, the decline of CD4+, however, the increase of CD8+ T-cell subtypes were observed in both, infected and uninfected mothers, respectively. The strong humoral response with the high production of IgM and $\operatorname{IgG} 2 \mathrm{~b}$ antibodies in infected mice was detected. In infected mothers, IgG2b level was higher than in infected nonpregnant mice during almost whole monitored period. In Group 1, delivery caused suppression of Th2 immune response, represented by IgG1, under the level observed in uninfected mothers. The findings show the changes in helper regulatory and cytotoxic immunity mechanisms of infected mothers. In offspring of infected mothers all IgG subclasses were detected, however specific IgM were not transmitted neither transplacentary, nor transmammary.
\end{abstract}

Keywords: Echinococcus multilocularis; mouse; pregnancy; immune response; offspring

\section{Introduction}

Echinococcus multilocularis, an intestinal cestode parasite of red foxes (Vulpes vulpes) and other carnivores, is the causative agent of human alveolar echinococcosis which is rare but mostly lethal infection in high percentage of untreated patients (Ammann \& Eckert, 1996; Gottstein \& Hemphill, 1997). The first confirmed finding of E. multilocularis in red foxes in Slovakia was recorded in 1999 at the border area with Poland (Dubinský et al., 1999). At present, this serious zoonosis occurs in animals and humans nearly on the whole territory of Slovakia (Kinčeková et al., 2005; 2008; Miterpáková et al., 2009).

The pregnancy and a simultaneous infection are important risk factors for mothers and their embryos and can modulate the subsequent immune response of the offspring for a longtime. Alveolar echinococcosis is a serious zoonosis caused by the larval stage of E. multilocularis. Larvocysts develop in different organs of intermediate hosts, as well as in humans (Eckert \& Deplazes, 1999; Vuitton, 2002). Secondary infection model, where mice are injected intraperitoneally with isolated protoscoleces from metacestode material, is characterised by switch from Th1 immune response in the early infection phase to Th2 response during chronic infection (Dvorožňáková et al., 2004). This type of alveolar echinococosis infection lacks the "early antigen phase", when the oncosphere and the early developing metacestode are presented to the immune system, and has an atypical localisation of the metacestode (peritoneal cavity). Changes in immune response caused by both, parasitic infection and pregnancy, do not influence reproduction potential of infected mice (Antolová \& Reiterová, 2010).

The proportion of CD4+ and CD8+ T lymphocytes and the balance between $\mathrm{Th} 1$ and Th2 cytokine profile appear to be crucial for metacestode growth (Bauder et al., 1999; Vuitton 2002; Borošková et al., 2003). Beside the significant cellular immune response, the humoral response has no direct restrictive role on the parasite growth but participates in immunopathological processes with a long term production of specific antibodies (Manfras et al., 2004).

The aim of the study was to follow up the influence of 
secondary Echinococcus multilocularis infection on cellular and humoral immune responses of mice, especially on the course of gravidity.

\section{Materials and methods}

\section{Biological material}

E. multilocularis metacestode (T1/85 strain, kindly provided by prof. Dr. Herbert Auer, Department of Medical Parasitology, Clinical Institute of Hygiene and Medical Microbiology, Medical University of Vienna, Austria) was maintained in Institute of Parasitology by intraperitoneal passage through Mongolian gerbils (Meriones unguiculatus). Protoscoleces were isolated from vesicular cysts 4 months post infection (p.i.). Parasite material was cut into small pieces in sterile RPMI-1640 medium (Sigma-Aldrich, Germany), supplemented with antibiotics $(100 \mathrm{U} / \mathrm{ml}$ penicillin and $100 \mu \mathrm{g} / \mathrm{ml}$ streptomycin (Sigma-Aldrich, Germany) and passed through a cell dissociation sieve tissue grinder kit using apertures ranging from 380 to $45.7 \mu \mathrm{m}$ (Sigma-Aldrich). Protoscoleces collected after the last filtration were counted and maintained in RPMI until use.

\section{Experimental design}

The experiment was carried out on 160 inbred female Balb/c mice, 2 months old, weighing $25-30 \mathrm{~g}$, kept under a 12 hour light/dark regime at room temperature $\left(21 \pm 3{ }^{\circ} \mathrm{C}\right)$ and $50-60 \%$ humidity on commercial diet and water.

Animals were randomly divided into 3 groups. Groups 1 and 2 (60 animals per Group) were intraperitoneally infected with homogenised metacestode material containing 2000 protoscoleces of E. multilocularis per animal. The control group (Group 3/40 animals) composed of healthy female mice exposed to a sham procedure by the administration of saline solution on the same day as experimental groups. Mice in Group 1 were fertilised on day 60 post infection, while Group 2 remained unfertilised and Group 3 was uninfected and fertilised on the same day as mice in Group 1. Offspring of infected and uninfected dams created Group 4 and 5, respectively.
In the course of 170 days post infection the production of different antibody classes and subclasses (IgM, IgG1, $\operatorname{IgG} 2 \mathrm{a}, \operatorname{IgG} 2 \mathrm{~b}$ ) were monitored in the both age categories, mothers and their offspring, respectively. The blood samples were taken from mothers on days $28,42,56,63,70$, $77,84,98,112,126,140$ and 170 post infection and from their offspring on days 1, 3, 5, 7, 21, 35 and 42 after birth. On the stated days five mice from each group and all their offspring were euthanized and the blood samples were examined separately.

Experiments were performed in accordance with national guidelines of the Slovak Republic. The experimental protocol was approved by the Institute of Parasitology Animal Care Committee.

\section{Detection of $\mathrm{CD} 4+$ and $C D 8+T$ lymphocytes}

Lymphocytes isolated from mice spleens were resuspended in PBS (pH 7.2) at final concentration $1 \times 10^{6}$ cells $/ \mathrm{ml}$. Cells were then incubated with directly-labelled rat anti-mouse CD4+ fluorescein isothiocyanate-conjugated and rat antimouse CD8+ phycoerythrin-conjugated monoclonal antibodies (Becton Dickinson Biosciences, PharMingen, Belgium) at the concentration $0.4 \mu \mathrm{g} / 10^{6}$ cells at $4{ }^{\circ} \mathrm{C}$ for $30 \mathrm{~min}$. After washing of cells three times with PBS containing $0.1 \%$ sodium azide, their number was analysed by Flow cytometry method (Dvorožňáková et al., 2000). Data for $10^{4}$ cells per sample falling within forward scatter (FSC) and side scatter (SSC) set for lymphocytes were collected with a FACScan flow cytometer (Becton Dickinson Biosciences, Germany). All data were analysed with CellQuest software.

Enzyme-linked immunosorbent assay for determination of specific antibody production

The production of various specific antibody classes and subclasses in mouse sera was determined by an indirect enzyme-linked immunosorbent assay (ELISA) (HavasiováReiterová et al., 1995) using partially purified antigen prepared from E. multilocularis metacestodes (Auer et al., 1988). Anti-mouse IgM, (Sigma, Germany) and IgG1,

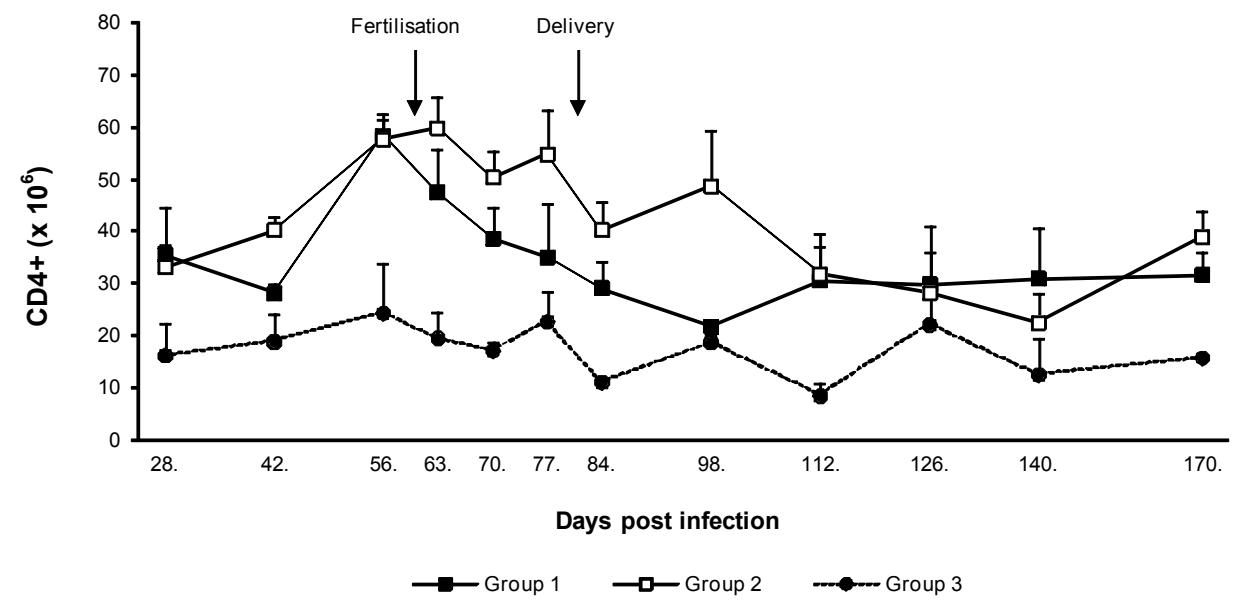

Fig. 1. Number of CD4+ T lymphocytes in fertilised and unfertilised mice infected with Echinococcus multilocularis and in uninfected fertilised control 
Table 1. Proportion of CD4+/CD8+ T lymphocytes

\begin{tabular}{lllllllllllll}
\hline Days p.i. & $\mathbf{2 8}$ & $\mathbf{4 2}$ & $\mathbf{5 6}$ & $\mathbf{6 3}$ & $\mathbf{7 0}$ & $\mathbf{7 7}$ & $\mathbf{8 4}$ & $\mathbf{9 8}$ & $\mathbf{1 1 2}$ & $\mathbf{1 2 6}$ & $\mathbf{1 4 0}$ & $\mathbf{1 7 0}$ \\
\hline Group 1 & 2.4 & 1.8 & 2.1 & 1.9 & 1.9 & 1.8 & 2.3 & 1.9 & 1.9 & 1.8 & 1.9 & 1.2 \\
Group 2 & 2.5 & 2.1 & 2.2 & 2.4 & 2.1 & 1.8 & 1.9 & 1.9 & 1.5 & 1.4 & 1.9 & 1.8 \\
Group 3 & 2.1 & 2.3 & 2.3 & 2.0 & 2.1 & 1.9 & 2.0 & 2.1 & 2.0 & 2.0 & 1.9 & 1.5 \\
\hline
\end{tabular}

IgG2a, IgG2b (Serotec Ltd, Oxford, UK) peroxidase-labelled conjugates were used at a dilution of 1:5000 and 1:1000, respectively. Chromogen o-phenylenediamine (Sigma-Aldrich, Steinheim, Germany) with $\mathrm{H}_{2} \mathrm{O}_{2}$ was applied as substrate. The reaction was stopped with $2 \mathrm{M}$ $\mathrm{H}_{2} \mathrm{SO}_{4}$. Optical densities (OD) were recorded spectropho-
Statistical evaluation

Statistical differences were assessed using Kruskal-Wallis analysis of variance (a value of $\mathrm{P}<0.05$ was considered to be significant), which allowed a comparison between the two groups. The analyses were performed using the Statistica 6.0 (Stat Soft, Tulsa, USA).

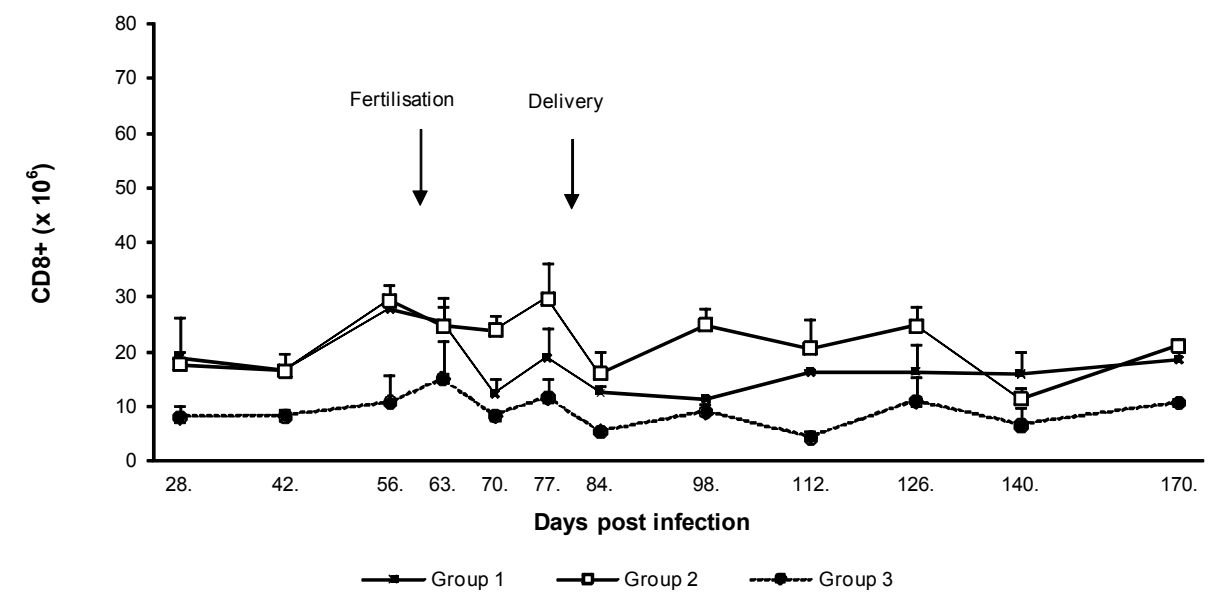

Fig. 2. Number of CD8+ T lymphocytes in fertilised and unfertilised mice infected with Echinococcus multilocularis and in uninfected fertilised control

tometrically at $492 \mathrm{~nm}$ (Revelation Quicklink, Opsys MR, Dynex Technologies, USA). Cut off values were determined individually for each antibody type by taking the average OD of uninfected control mice plus 3 standard deviations (S.D.).

\section{Results}

Number of CD4+ and CD8+ T lymphocytes

The number of both CD4+ and CD8+ T lymphocytes was higher in non-pregnant infected mice (Group 2) than in the both groups of pregnant animals, infected and uninfected ones (Groups 1 and 3).

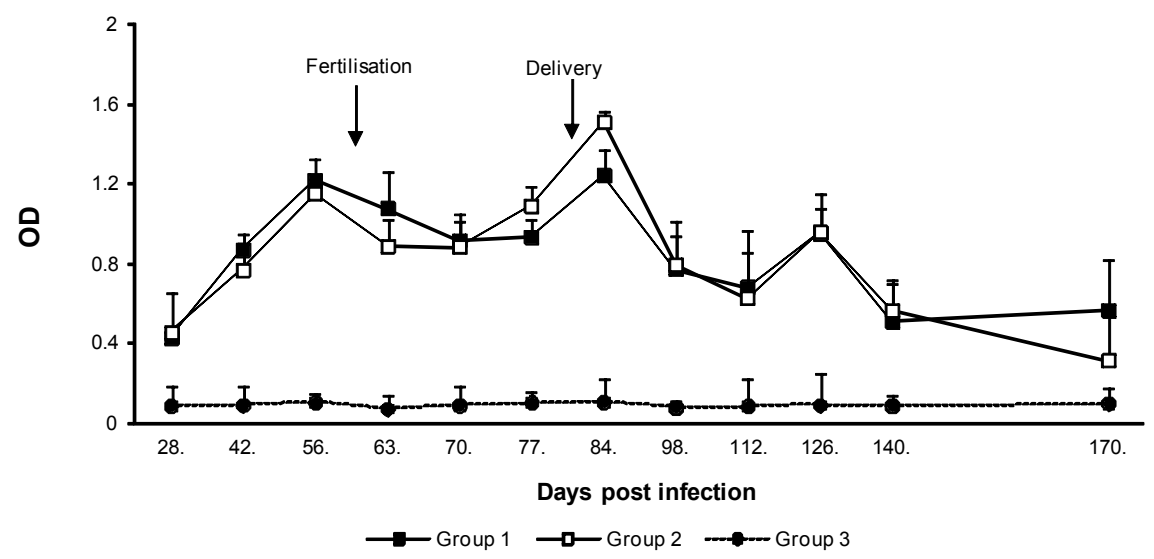

Fig. 3 Course of IgM antibody response in Balb/c mice infected with Echinococcus multilocularis 

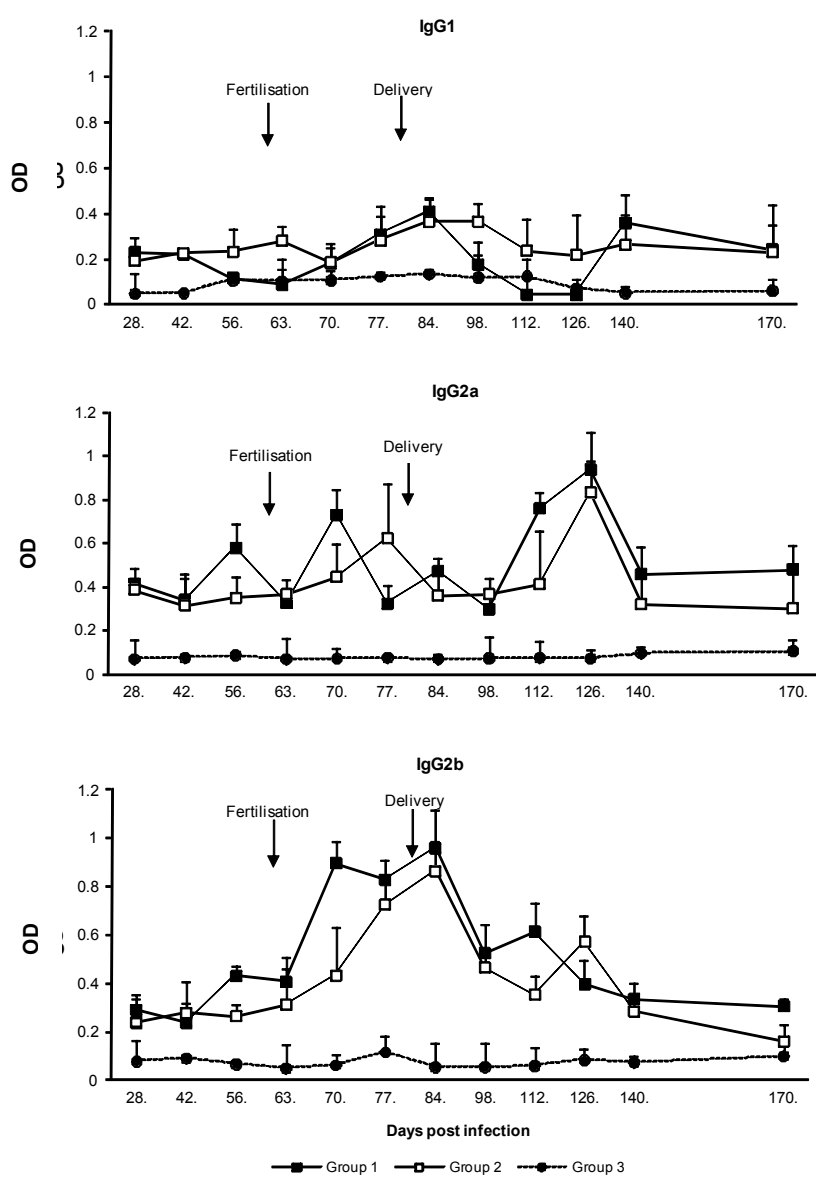

Fig. 4. Kinetics of specific IgG1, IgG2a and IgG2b antibodies in $\mathrm{Balb} / \mathrm{c}$ mice infected with Echinococcus multilocularis

In infected mothers the decrease in CD4+ T lymphocyte population was observed between days 56 and 98 post infection (p.i.). Their number elevated on day 112 p.i. and remained stable till the end of observation. Significant differences in the proportion of CD4+ subpopulation were detected between infected fertilised and unfertilised mice (Groups 1, 2) only on day 98 p.i. $(\mathrm{P}<0.05)$ (Fig. 1). The number of $\mathrm{CD} 8+\mathrm{T}$ lymphocytes was also higher in both infected groups then in uninfected mothers. In infected mothers (Group 1) its decrease was observed after the first trimester of pregnancy. Then, before the delivery, the increase of $\mathrm{CD} 8+\mathrm{T}$ cell number was recorded, following by stabilisation of its level until the end of experiment. Significant differences in the proportion of CD8+ subtype were detected between infected mice (Group 1,2) on day 70 and 98 p.i. ( $\mathrm{P}<0.05$ and $\mathrm{P}<0.01$, respectively) (Fig. 2). The proportion of $\mathrm{CD} 4+/ \mathrm{CD} 8+\mathrm{T}$ lymphocytes between examined Groups of mice varied between rates 1.2 and 2.5, however without any significant differences on particular days of experiment (Table 1).

\section{Specific antibody production}

Strong humoral IgM response was detected in both infected groups, without any significant differences during pregnancy and in post partum period (Group 1 versus Group 2) (Fig. 3).

The production of IgG1 subclass was slightly depressed in the first trimester of pregnancy of infected mice (Group 1). Then, its production was similar than in infected unfertilised mice (Group 2). After delivery antibody level decreased and reached lower values than in uninfected mothers (Group 3) on days 112 and 126 p.i.. After 140 dpi the level was comparable to infected unfertilised mice (Group 2) (Fig.4).

IgG2a antibody response was similar in both infected groups (Group 1 and 2) during the whole monitored period.

The course of $\operatorname{IgG} 2 \mathrm{~b}$ production was also similar in both, fertilised and unfertilised infected mice groups, except for the pregnancy period, when IgG2b antibody level in Group 1 was slightly enhanced (Fig 4).

The IgM antibodies were transmitted neither transplacentary nor transmammary from mothers to their offspring (Fig. 5). Specific antibodies of IgG2a and IgG2b subclasses in offspring of infected mothers (Group 4) were detected already on the first day post partum, while IgG1 appeared on day 3 post partum. The temporary increase in IgG1 and IgG2a subclasses, on 21. and 35. dpi respectively, suggests their transmammary transmission (Fig. 6).



Fig. 5. IgM antibody level in offspring of Balb/c mice infected with Echinococcus multilocularis 

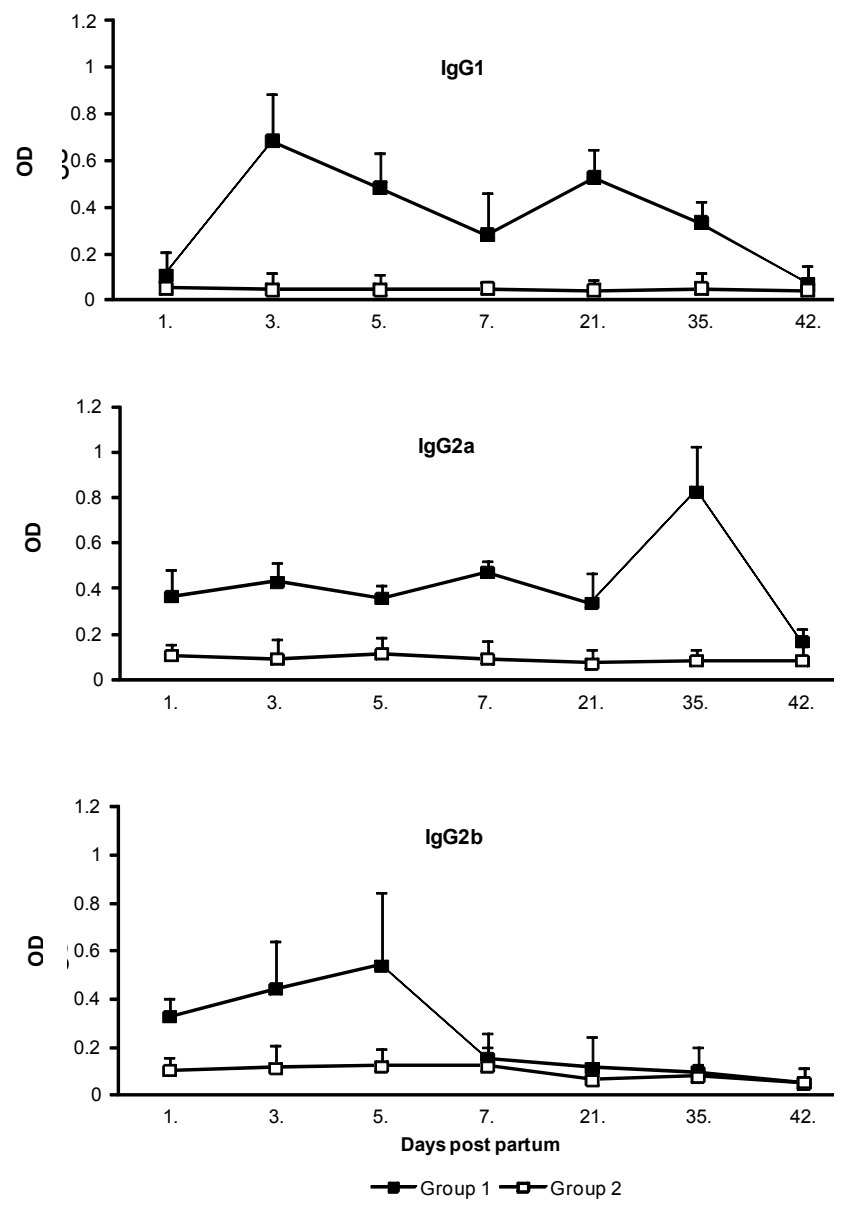

Fig. 6. Kinetics of specific IgG1, IgG2a and IgG2b antibodies in offspring originating from Balb/c mice infected with Echinococcus multilocularis

\section{Discussion}

Balb/c mice strain has been found to be particularly susceptible to E. multilocularis infection with an intensive intraperitoneal metacestode proliferation and metastasis formation, in various inner organs (Gottstein \& Felleisen, 1995). T-lymphocytes play a major role in the control of immune response in E. multilocularis infected intermediate host (Dvorožňáková et al., 2008). The helper CD4+ T lymphocytes are essential for activation, differentiation, and isotype regulation of B lymphocytes and are of significant help in antigen presentation. After the antigen stimulation they release a whole range of cytokines, as regulatory mediators that determine the development of immune response to Th1 or Th2 type (Emery et al., 1996; Dvorožňáková et al., 2009). Cytotoxic CD8+ T lymphocytes are responsible for the destruction of structures carrying an antigen on their surface, participate in the inhibition of immune response and regulate eosinophilia (Owhashi et al., 1998). Proportions of CD4+ and CD $8+\mathrm{T}$ cell subsets appear to be important for the metacestode growth. Relatively high number of CD4+ T cells correlates with abortive or slow development of the larvae, while CD8+ T cells are predominant in severe cases of alveolar echinococcosis (Vuitton, 2002; Vuitton et al., 2006; Yang et al., 2005). During the course of gravidity and post partum period the number of both subtypes of $\mathrm{T}$ lymphocytes was lower in pregnant animals comparing with non-pregnant mice suggesting the down-regulation of $\mathrm{T}$ cells subpopulations caused by pregnancy. The decline of CD4+ and rise of CD8+ T cell numbers observed in both, infected and uninfected mothers, in late pregnancy correlates with findings of other authors (Landers et al., 1991), who observed the decrease of CD4+ and increase of CD8+ T cells at the terminal phase of physiological pregnancy.

Basically, the production of $\operatorname{IgM}$ and all $\mathrm{IgG}$ subclasses is stimulated by antigens from metacestode laminar layers, the source of host's antigen stimulation in chronic course of the disease. Th2 response is characterised by the activation of $\mathrm{B}$ cells and by a subsequent production of $\mathrm{IgE}$, IgG1, IgG4 and IgA antibodies. On the other hand, Th1 response is characterised by $\operatorname{IgG} 2 \mathrm{a}, \mathrm{IgG} 2 \mathrm{~b}$ and $\mathrm{IgG} 3$ production (in hosts resistant to infection).

In our experimentally infected dams, strong humoral response with high production of $\operatorname{IgM}$ and $\operatorname{IgG} 2 \mathrm{~b}$ antibodies was detected. IgG1 level, related to Th2 immune response, was suppressed in infected mothers after the delivery, when, the antibody levels declined under the level of uninfected mothers. IgG2a and IgG2b antibody response was similar in both infected groups. Both antibody subclasses slightly declined in infected dams in the third trimester of gravidity. On the other hand, in different mouse strains (C57BL6J), susceptible to E. multilocularis infection, low production of IgG2a immunoglobulins have been observed (Bauder et al., 1999).

A specific antibody production in progeny starts already in the early gestation period, but due to the sterile surroundings of the foetus its level is very low (Buc, 1997). In our experiment, IgM antibodies were transmitted neither transplacentary nor transmammary. IgG1 subclass seems to be transmitted only transmammary, because it was detected on the $3^{\text {rd }}$ day post partum and persisted for 5 weeks. $\mathrm{IgG} 2 \mathrm{a}$ and $\mathrm{IgG} 2 \mathrm{~b}$ subclasses were detected in offspring of infected mothers already on the first day post partum. Later temporary increase of $\operatorname{IgG} 2$ a subclass suggests also its transmammary transmission.

Alveolar echinococcosis is not transmitted to offspring; therefore no impulse for specific antibody production in young ones exists. After the birth, antibodies acquired from mothers progressively decline and usually persist in the blood circulation only for several weeks post partum. In our experiment, IgG2a persisted almost at the same level for 5 weeks, while IgG2b rapidly decreased after $5^{\text {th }}$ day post partum.

A successful pregnancy results from a state of "tolerance" of the mother. A special type of cells called a regulatory $\mathrm{T}$ cells, is known to prevent immune system from attacking own tissues. These regulatory $\mathrm{T}$ cells now seem to play a key role in preventing mother from rejecting her embryo (Raghupathy, 1997). In our former studies, in the group of infected, fertilised mice increased Th2 cytokine (IL-10) 
concentrations from the day 70 p.i. until the end of experiment was found, what correlates with observed more intensive metacestode growth (Antolová \& Reiterová, 2010). We can hypothesise that changes in Th1 and Th2 response could influence both, the course of gravidity and infection. E. multilocularis infected mice were fertilised on day 60 p.i., in the period characterised by relatively rapid cyst growth. Although, not observed in this experiment, Th2 overactivity induced by pregnancy can be associated with the more rapid growth of metacestodes in fertilised mice observed by Antolová \& Reiterová (2010). After all, these changes should influence also humoral immune response with the production of specific antibody subclasses, as well as their transmission into the progeny.

In the light of these data the changes in $\mathrm{Th} 1 / \mathrm{Th} 2$ production did not significantly influence the course of gravidity. On the other hand, more intensive metacestode growth was observed after the delivery, which confirmed the ability of host organism to adapt to severe damage caused by $E$. multilocularis, not only in normal physiological, but also during pregnancy (Antolová \& Reiterová, 2010). Understanding the immune system is crucial for both, medical and bioscience studies, with new research revealing yet more secrets year on year.

\section{Acknowledgement}

The publication has been realized within a frame of the project Centre of Excellence for Parasitology (Code ITMS: 26220120022) based on the support of the Operational Programme "Research \& Development" funded from the European Regional Development Fund (rate 0.6) and was supported by the Slovak Science Grant Agency (VEGA), Grant No. 2/0145/09.

\section{References}

AMMANN, R., W., ECKERT, J. (1996): Cestodes: Echinococcus. In: WeInStOCK, J.V. (Ed) Parasitic diseases of the liver and intestines. Philadelphia PA, Saunders, pp. 655 - 689

AntolovÁ, D., ReITEROVÁ, K. (2010): Influence of Echinococcus multilocularis infection on reproduction and cellular immune response of mice. Parasite Immunol., 32: 384 - 387. DOI: 10.1111/j.1365-3024.2009.01194.x

Auer, H., Hermentin, K., AspöcK, H. (1988): Demonstration of a Specific Echinococcus multilocularis Antigen in the Supernatant of in vitro Maintained Protoscolices. Zentralbl. Bakteriol. Mikrobiol. Hyg. A, 268: 416 - 423

Bauder, B., Auer, H., Schilcher, F., Gabler, C., Romig, T., BILGER, B., Aspock, H. (1999): Experimental investigation on the $\mathrm{B}$ and $\mathrm{T}$ cell immune response in primary pelvic echinococcosis. Parasite Immunol., 21: $409-$ 421. DOI: 10.1046/j.1365-3024.1999.00241.x

BoreckA, A., GAWOR, J., MALCZEWSKA, M. (2008): Occurrence of Echinococcus multilocularis in red foxes (Vulpes vulpes) in southern Poland. Helminthologia, 45: 24 - 27. DOI: $10.2478 / \mathrm{s} 11687-008-0004-5$
BorošKovÁ, Z., DVOrožŇÁKOvÁ, E., ŠEvČíKOvÁ, Z. (2003): Cellular immune reactions of mice with alveolar echinococcosis after albendazole therapy. Helminthologia, 40: $187-194$

BuC, M. (1997): Clinical Immunology. Bratislava, Veda, pp. 364 (In Slovak)

DUBINSKÝ, P., SVOBODOVÁ, V., TURČEKOVÁ, L., LITERÁK, I., MartíneK, K., ReITEROVÁ, K., KolÁŘOVÁ, L., KlimeŠ, J., MrLíK, V. (1999): Echinococcus multilocularis in Slovak Republic: The first record in red foxes (Vulpes vulpes). Helminthologia, 36: 105 - 110

DVOROŽŇÁKOVÁ, E., BOROŠKOVÁ, Z., DuBINSKÝ, P., TOMAŠOVIČOVÁ, O., MACHNICKA, B. (2000): Toxocara canis in mice: immune response after infection and immunization. Helminthologia 37: $199-204$

DVOrož̌ÁkOvÁ, E., HrČKovÁ, G., BorošKovÁ, Z., VELEBNÝ, S., DUBINSKÝ, P. (2004): Effect of treatment with free and liposomized albendazole on selected immunological parameters and cyst growth in mice infected with Echinococcus multilocularis. Parasitol. Int., 53: 315 - 325. DOI:10.1016/j.parint.2004.05.001

DVORožŇÁKOVÁ, E., PORUBCOVÁ, J., ŠNÁBEL, V., FEDOROČKO, P. (2008): Immunomodulative effect of liposomized muramyltripeptide phosphatidylethanolamine (LMTP-PE) on mice with alveolar echinococcosis and treated with albendazole. Parasitol. Res., 103: 919 - 929. DOI: 10.1007/s00436-008-1077-2

DvorožnÁKovÁ, E., PorubcovÁ, J., ŠEvČíKovÁ, Z. (2009): Immune response of mice with alveolar echinococcosis to therapy with transfer factor, alone and in combination with albendazole. Parasitol. Res., 105: $1067-1076$. DOI: $10.1007 / \mathrm{s} 00436-009-1520-\mathrm{z}$

ECKERT, J., DEPLAZES, P. (1999): Alveolar echinococcosis in humans: the current situation in Central Europe and the need for countermeasures. Parasitol. Today, 15: 315 - 319 EMERy, I., Liance, M., Deriaud, E., Vuiton, D., Houin, R., LECLER, C. (1996): Characterisation of T-cell immune response to Echinococcus multilocularis infected C57BL/6J mice. Parasite Immunol., 18: 463 - 472

Gottstein, B., Felleisen, R. (1995): Protective Immune Mechanisms against the Metacestode of Echinococcus multilocularis. Parasit. Today, 11: $320-326$

GotTstein, B., HeMPhiLl, A. (1997): Immunopathology of echinococcosis. Chem. Immunol., 66: 177 - 208

HAVASIOVÁ-REITEROVÁ, K., TOMAŠOVIČOVÁ, O., DUBINSKÝ, P. (1995): Effect of various doses of infective Toxocara canis and Toxocara cati eggs on humoral response and distribution of larvae in mice. Parasitol. Res., 81: 13 - 17

KinČEKOVÁ, J., DubinskÝ, P. JR., DVOroŽŇÁKOVÁ, E., AuER, H., HudačKovÁ, J., DAŇOVÁ, M., Stanislayová, M., Straka, L., Szilágyiová, M. (2005): Occurrence, classification and diagnostics of human alveolar echinococcosis in Slovakia. Czech Slov. Gastroent. Hepatol., 59: $11-16$ (In Slovak)

KinčekovÁ, J., HrČKovÁ, G., Bober, J., VrZnula, A., SzabadosovÁ, V., BoHUŠ, P., ZACHAR, M., (2008): A rare case of alveolar echinococcosis in a 14-year-old child. 
Helminthologia, 45: 28 - 31. DOI: 10.2478/s11687-0080004-5

Landers, D. V., Bronson, R. A., Pavia, C. S., Stites, D. P. (1991): Immunology and reproduction. In STITES D.P, TERR A.I. (Eds.): Basic and Clinical Imunology. Victoria Publishing, San Francisco, Harvard Funds 17, pp. 180 - 210 Manfras, B. J., Reuter, S., Wendland, T., Boehm, B. O. (2004): Impeded Th1 CD4 memory T cell generation in chronic-persisting liver infection with Echinococcus multilocularis. Int. Immunol., 16: 43 - 50. DOI: 10.1093/intimm/dxh005

MiterpákOvÁ, M., HurníkovÁ, Z., AntolovÁ, D., DUBINSKÝ, P. (2009): Endoparasites of red fox (Vulpes vulpes) in the Slovak Republic with the emphasis on zoonotic species Echinococcus multilocularis and Trichinella spp. Helminthologia, 46: 73 - 79. DOI: 10.2478/s11687-009-0015-X

OWhashi, M., ARIT. H., NiwaQ, A. (1998): Production of eosinophil chemotactic factor by CD8+ T-cells in Toxocara canis-infected mice. Parasitol. Res., 84: 136 - 138

RAGHUPATHY, R. (1997): Th1-type immunity is incompatible with successful pregnancy. Immunol. Today., 18: $478-482$

VUITTON, D.A. (2002): The ambiguous role of immunity in echinococcosis, protection of the host or of the parasite? Acta Tropica, 85: $119-132$

Vuitton, D.A., Zhang, S.L., Yang, Y., Godot, V., Beurton, I., Mantion, G., Bresson-Hadni, S. (2006): Survival strategies of Echinococcus multilocularis in the human host. Parasitol. Int., 55: S51 - S55. DOI: 10.1016/j.parint.2005.11.007

YAng, Y.R., Vuitton, D.A., Jones, M.K., CRAiG, P.S., MCMANUS, D.P. (2005): Brain metastasis of alveolar echinococcosis in hyperendemic focus of Echinococcus multilocularis infection. Trans. Roy. Soc. Trop. Med. Hyg., 99: $937-941$ 